\title{
Virulence of luminous vibrios to Artemia franciscana nauplii
}

\author{
S. A. Soto-Rodriguez ${ }^{1}$, A. Roque ${ }^{2}$, M. L. Lizarraga-Partida ${ }^{1}$, A. L. Guerra-Flores ${ }^{3}$, \\ B. Gomez-Gil ${ }^{2, *}$
}

\author{
${ }^{1}$ Department of Marine Biotechnology, Centro de Investigación Científica y de Educación Superior de Ensenada (CICESE), \\ Ensenada 22860, Baja California, Mexico \\ ${ }^{2}$ (CIAD), A.C. Mazatlán Unit for Aquaculture and Environmental Management, AP 711 Mazatlán, Sinaloa 82000, Mexico \\ ${ }^{3}$ Universidad Autónoma de Sinaloa, Paseo Claussen s/n, Mazatlán, Sinaloa 82000, Mexico
}

\begin{abstract}
From healthy and diseased penaeid shrimp from Asia and the Americas, 25 luminous and 2 non-luminous bacterial strains were isolated, and 14 were phenotypically identified as Vibrio harveyi; 9 isolates produced significant mortalities (45 to $80 \%$ ) in Artemia franciscana nauplii at inoculation densities of $10^{5}$ to $10^{6} \mathrm{CFU} \mathrm{m}{ }^{-1}$ compared to the controls (unchallenged nauplii). The maximum number of bacteria ingested (bioencapsulated) by the Artemia nauplii varied from less than 10 to $10^{3} \mathrm{CFU}$ nauplius ${ }^{-1}$ and no significant relationship was observed between the density of bacteria inoculated, the amount of bacteria ingested, and naupliar mortality. Significant correlations were obtained between naupliar mortality and production of proteases, phospholipases or siderophores, but not between mortality and lipase production, gelatinase production, hydrophobicity or hemolytic activity. The results suggest that virulence of the strains tested was more related to the production of particular exoenzymes than to the measured colonization factors.
\end{abstract}

KEY WORDS: Pathogenicity $\cdot$ Luminous Vibrio $\cdot$ Hydrophobicity $\cdot$ Exoenzymes $\cdot$ Artemia

\section{INTRODUCTION}

Luminous vibrios are natural inhabitants of coastal waters (Ruby \& Nealson 1977) and shrimp hatchery systems (Abraham \& Manley 1995, Abraham et al. 1997, Jun \& Huai-Shu 1998). However, during some disease epizootics, luminous Vibrio spp. counts can increase 1000-fold inside larval rearing tanks, leading to bacterial infection by an oral route (Lavilla-Pitogo et al. 1990). Luminous vibriosis is caused mainly by strains of $V$. harveyi but occasionally also by $V$. splendidus Biovar I, and it is a serious threat to penaeid shrimp hatcheries (Song \& Lee 1993, Karunasagar et al. 1994, Lavilla-Pitogo 1995). V. harveyi has been associated with mortalities of penaeid shrimp larvae in the Philippines (Baticados et al. 1990, Lavilla-Pitogo et al. 1990), Thailand (Jiravanichpaisal et al. 1994), India (Karunasagar et al. 1994), Indonesia (Prayitno \& Latchford 1995), Australia (Pizzutto \& Hirst 1995), Venezuela (Alvarez et al. 1998) and Ecuador (Robertson et al.
1998). Additionally, there is an increasing list of aquatic animals for which $V$. harveyi has also been reported as a major pathogen, including finfish (Balebona et al. 1995, Saeed 1995), bivalves (Pass et al. 1987) and phyllosoma larvae of the lobster Jasus verreauxi (Diggles et al. 2000).

Karunasagar et al. (1994) showed that antibioticresistant isolates of Vibrio harveyi could produce between 44 and $80 \%$ mortality in Penaeus monodon postlarvae after a $5 \mathrm{~d}$ exposure. A study of $P$. vannamei protozoea immersed for $2 \mathrm{~h}$ in a suspension of $V$. harveyi (Isolate STD3-101) at densities from $10^{4}$ to $10^{7}$ $\mathrm{CFU} \mathrm{ml}{ }^{-1}$ showed mortalities of 51 and $90 \%$, respectively (Robertson et al. 1998). When $P$. monodon protozoea were challenged with $2 \mathrm{~V}$. harveyi isolates at $10^{4}$ and $10^{6} \mathrm{CFU} \mathrm{ml}{ }^{-1}$ (Harris \& Owens 1999), mortalities ranged from 50 to $100 \%$ after $40 \mathrm{~h}$ exposure. The problem with bath challenges of shrimp larvae is the lack of reproducibility. Therefore, there is a need to standardize in vivo procedures that can reproduce natural 
conditions and be used to verify the bacterial virulence of isolates from crustacean culture systems.

Antibiotics have been incorporated into live Artemia spp. nauplii for delivery to aquatic animal larvae (Mohney et al. 1990, Chair et al. 1991, Touraki et al. 1995, Roque et al. 1998), a process known as bioencapsulation. Bacteria have been similarly incorporated to evaluate their pathogenic, probiotic, or therapeutic potential (Rico-Mora \& Voltolina 1995, Gomez-Gil et al. 1998, Roque et al. 2000). For example, bioencapsulated fish pathogenic bacteria have been used to investigate the infection route in turbot larvae (Chair et al. 1994) and to vaccinate fish fry (Campbell et al. 1993) and juvenile carp (Joosten et al. 1995).

The aim of the present study was to examine the relationship between mortality in Artemia franciscana nauplii and various properties of luminous Vibrio spp. isolates obtained from seawater or diseased shrimp (larvae and juveniles) from Asia and the Americas.

\section{MATERIALS AND METHODS}

Isolation and preservation of bacteria. Seventeen luminous and non-luminous bacteria were isolated from shrimp larvae, larval rearing water, and nearby coastal seawater of 3 shrimp hatcheries of northwestern Mexico (Table 1), and from diseased shrimp larvae and juveniles from the Philippines, Ecuador, and China. Strains were first isolated and partially purified on thiosulphate-citrate-bile-sucrose agar (TCBS, Difco), purified on tryptic soy agar (TSA, Bioxon), supplemented with $2.0 \%$ sodium chloride $(\mathrm{NaCl})$, and incubated at $30^{\circ} \mathrm{C}$ for 18 to $24 \mathrm{~h}$. Vibrio harveyi ATCC 14126 and $V$. alginolyticus ATCC 17749 were used as reference strains. All isolates were preserved in cryovials at $-70^{\circ} \mathrm{C}$ in an ultra-low mechanical freezer (Revco Scientific) according to the methodology proposed by Gherna (1994).

Bacterial inoculum. To recover the isolates for use in experiments, a bead from the cryovial was placed in $10 \mathrm{ml}$ of tryptic soy broth (TSB, Bioxon) $+2.0 \% \mathrm{NaCl}$, followed by incubation at $30^{\circ} \mathrm{C}$ overnight with constant agitation. Then, a loop full of the bacterial broth was streaked on TSA $+2.0 \% \mathrm{NaCl}$ followed by incubation at $30^{\circ} \mathrm{C}$ for 20 to $24 \mathrm{~h}$. Several colonies were subsequently taken and suspended in $10 \mathrm{ml}$ of sterile saline solution $(2.5 \% \mathrm{NaCl})$ to achieve an optical density of 1.0 at $610 \mathrm{~nm}$, similar to a 0.5 MacFarland standard $\left(10^{8} \mathrm{CFU} \mathrm{ml} \mathrm{ml}^{-1}\right)$. These saline bacterial suspensions (SBS) were used as the inoculum for Artemia franciscana challenges. To confirm the bacterial density obtained, the SBS were serially diluted in sterile saline solution and $0.1 \mathrm{ml}$ was spread on TSA plates. The plates were incubated overnight at $30^{\circ} \mathrm{C}$, and the colony forming units counted. The bacterial density used in all bath challenges was between $10^{5}$ and $10^{6} \mathrm{CFU} \mathrm{ml}{ }^{-1}$.

Bacterial characterization. Biochemical tests to characterize the isolates were performed following the

Table 1. List of Vibrio strains employed in this study

\begin{tabular}{|c|c|c|c|}
\hline Strain & Identification & Source & Origin \\
\hline V. harveyi & Type strain & ATCC14126 dead amphipod Talorchestia sp. & Rockville, Massachusetts, USA \\
\hline V. alginolyticus & Type strain & ATCC17749 Spoiled horse mackerel & Japan \\
\hline $1 \mathrm{~A}$ & V. harveyi & Near-shore seawater & $\begin{array}{l}\text { Santa Barbara Bay, Sonora, Mexico } \\
\text { (Penaeus stylirostris) }\end{array}$ \\
\hline $2 \mathrm{MZ}$ & V. alginolyticus & Seawater from a broodstock tank & $\begin{array}{l}\text { Hatchery in Mazatlan, Sinaloa, Mexico } \\
\text { (Penaeus stylirostris) Sinaloa }\end{array}$ \\
\hline $10 \mathrm{MZ}$ & V. harveyi & Nauplii & " \\
\hline $11 \mathrm{MZ}$ & V. harveyi & Nauplii & " \\
\hline STD3-131 & V. harveyi & Diseased postlarvae & Ecuador (Penaeus vannamei) \\
\hline STD3-1002 & V. harveyi & Diseased postlarvae, not luminous & China \\
\hline ML & $V$. alginolyticus & Shrimp larvae & $\begin{array}{l}\text { Hatchery in La Paz, Baja California } \\
\text { Sur, Mexico (Penaeus vannamei) }\end{array}$ \\
\hline Ea & $V$. harveyi & Hatching system & $\begin{array}{l}\text { Hatchery in Santa Clara Gulf, Sonora, } \\
\text { Mexico (Penaeus stylirostris) }\end{array}$ \\
\hline $\mathrm{Na}$ & V. harveyi & Shrimp nauplii & " \\
\hline $\mathrm{Z}_{1}$ & $V$. harveyi & Bottom seawater from broodstock tank & " \\
\hline $\mathrm{Z}_{2}$ & V. harveyi & Surface seawater from broodstock tank & $"$ \\
\hline $\mathrm{Z}_{3}$ & V. harveyi & Wall tank seawater from broodstock tank & $"$ \\
\hline $\mathrm{M}_{1}$ & $V$. harveyi & Bottom seawater from broodstock tank & $"$ \\
\hline PL96-11-6 & V. harveyi & Diseased postlarvae & Philippines ( $P$. monodon) \\
\hline AP9701 & $V$. vulnificus & Hepatopancreas from diseased juveniles & " \\
\hline PN9801 & V. harveyi & Lymphoid organ from diseased juveniles & $"$ \\
\hline IPL8 & V. harveyi & Postlarvae with luminescent vibriosis & " \\
\hline
\end{tabular}


scheme of Alsina \& Blanch (1994) and according to the methodologies of MacFaddin (1990) and Cowan et al. (1993), except that $\mathrm{NaCl}$ was added to a final concentration of $2.5 \%$ to allow growth of the isolates.

Challenge with Artemia franciscana nauplii. The overall scheme for the challenge tests is shown in Fig. 1. A. franciscana cysts from the Great Salt Lake (Prime Artemia) were employed in this study. Sterile Artemia nauplii were prepared following the methodology of Gomez-Gil et al. (1998). Briefly, newly hatched nauplii were collected in a $120 \mu \mathrm{m}$ sterile sieve and washed thoroughly with sterile seawater,

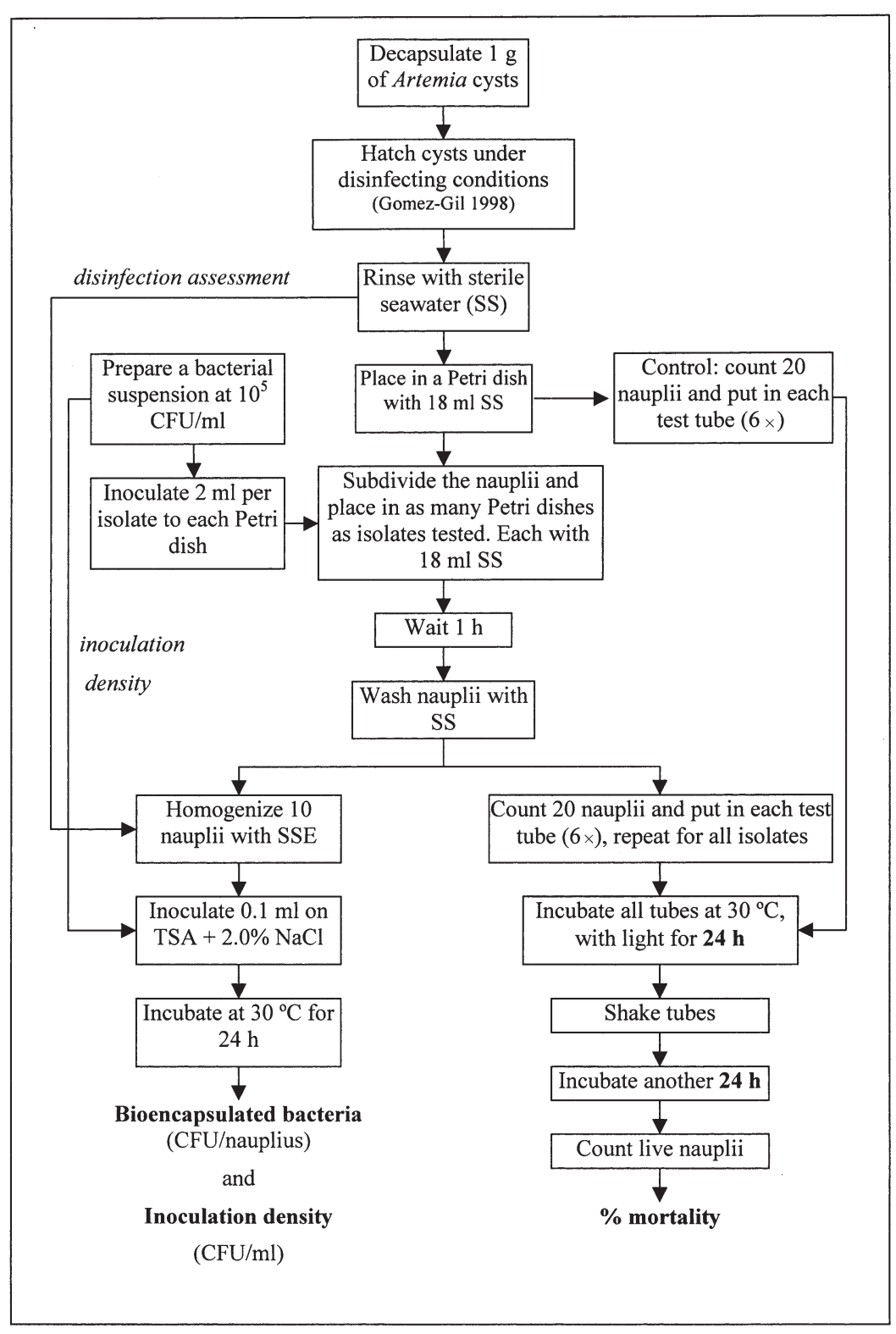

Fig. 1. Flow chart of protocol used in experimental challenge tests with Artemia franciscana. SS: sterile saline; TSA: tryptic soy agar before being placed in a petri dish with $18 \mathrm{ml}$ of sterile seawater. For controls, nauplii were removed and placed $(20$ each) in 6 glass test tubes $(18 \times 150 \mathrm{~mm})$ containing $20 \mathrm{ml}$ of sterile seawater previously shaken for oxygenation. The remaining nauplii were subdivided and placed in petri dishes containing sterile seawater $(18 \mathrm{ml})$, in as many petri dishes as different bacterial strains to be tested; $2 \mathrm{ml}$ SBS from each experimental isolate were added to the appropriate petri dish to obtain a bacterial density of $10^{5} \mathrm{CFU} \mathrm{ml}^{-1}$. This protocol permitted the nauplii to incorporate bacteria as soon as their mouths opened (Gomez-Gil et al. 1998). After $1 \mathrm{~h}$ exposure, the nauplii were washed thoroughly with sterile seawater and then subdivided into 20 nauplii each in 6 replicate test tubes for each tested bacterial isolate.

All experimental tubes were incubated for $48 \mathrm{~h}$ in a water bath at $30^{\circ} \mathrm{C}$ with constant agitation and lighting. At $24 \mathrm{~h}$, the tubes were thoroughly shaken to oxygenate the water. At $48 \mathrm{~h}$, the number of living nauplii was counted. Five experiments were conducted, each with 4 different isolates and a control (no bacterium inoculated). Expt 6 was done to evaluate reproducibility of the 3 most significantly pathogenic isolates, 1 non-pathogenic isolate and the control.

Uptake of bacteria by Artemia franciscana nauplii. Ten nauplii remaining from each test in the previous experiment were collected and homogenized together in $100 \mu$ of sterile saline (SSE). The entire homogenate was then plated in TSA $+2.0 \% \mathrm{NaCl}$ and incubated for $24 \mathrm{~h}$ at $30^{\circ} \mathrm{C}$. This evaluation was run in duplicate.

Salt-aggregation test (SAT). The test of Lindahl et al. (1981) as modified by Lee \& Yii (1996) was used. Each isolate was washed with $2.5 \%$ $\mathrm{NaCl}$ sterile saline solution and suspended in $0.002 \mathrm{M}$ sodium phosphate buffer ( $\mathrm{pH}$ 6.8). The optical density of each bacterial suspension was adjusted to 1.0 at $420 \mathrm{~nm}$. An aliquot of $30 \mu \mathrm{l}$ of this suspension (in duplicate) was mixed with an equal volume of each concentration of ammonium sulfate $\left(\mathrm{NH}_{4}\right)_{2} \mathrm{SO}_{4}$ from 0.05 to $4.0 \mathrm{M}$ in 96-well micro-titer plates. The plates were kept at room temperature for $3 \mathrm{~h}$. The SAT value was defined as 
the lowest molarity of ammonium sulfate that caused visible agglutination of a test organism.

Bacterial adhesion to hydrocarbons test (BATH). The method of Rosenberg et al. (1980) was used. Briefly, suspensions of tested isolates were adjusted to an absorbency of 0.16 at $600 \mathrm{~nm}$ with saline phosphate buffer ( $\mathrm{pH}$ 7.2). The suspension was overlaid with 5 different volumes of n-octane (Sigma) in $10 \mathrm{~mm}$ glass tubes. After 2 min of constant agitation, the mixtures were allowed to separate for $15 \mathrm{~min}$. Finally, the absorbency at $600 \mathrm{~nm}$ of the aqueous phase was registered and the percentage of partition in the hydrocarbon phase was calculated using the following formula:

$\frac{A_{600}(\text { original bacterial suspension })-A_{600}(\text { aqueous phase })}{A_{600}(\text { original suspension bacterial })} \times 100$

Hydrophobicity. The criteria proposed by Santos et al. (1990) were used to evaluate the hydrophobicity of each isolate tested in this study. Interpretations were as shown for the SAT test $(0.0$ to $1.0 \mathrm{M}=$ strongly hydrophobic, 1.0 to $2.0 \mathrm{M}=$ moderately hydrophobic, 2.0 to $4.0 \mathrm{M}=$ weakly hydrophobic, and $>4.0 \mathrm{M}=$ not hydrophobic) and the BATH-test (>50\% partitioning = strongly hydrophobic, 20 to $50 \%$ partitioning $=$ moderately hydrophobic, and $<20 \%$ partitioning = not hydrophobic).

Enzymatic activity. Bacterial overnight cultures were spot-inoculated onto TSA with $2.0 \% \mathrm{NaCl}$ that contained $1 \%$ gelatin (gelatinase test), $0.2 \%$ egg yolk (lipase test) or $1 \%$ Tween 80 (phospholipase test). The plates were incubated in a humidified chamber for $24 \mathrm{~h}$ at $30^{\circ} \mathrm{C}$ and the diameter of the lytic halo around each well was measured. Protease activity was examined by a filter-paper method following Morita et al. (1994). Briefly, sterile filter paper disks (Whatman no. 2, $8 \mathrm{~mm}$ diameter) were soaked with 10 and $20 \mu \mathrm{l}$ SBS of each test isolate and then left to dry before being placed on TSA with $2.0 \% \mathrm{NaCl}$ and $0.5 \%$ skim milk as substrate. The plates were incubated for $24 \mathrm{~h}$ at $30^{\circ} \mathrm{C}$, after which the disks were soaked with $5 \%$ trichloroacetic acid for $1 \mathrm{~h}$. For all these hydrolytic assays, the diameter of the lytic halo around each paper disk was measured and subtracted from the disc diameter $(8 \mathrm{~mm})$ to give the relative hydrolysis activity (mm) and 6 to $8 \mathrm{~mm}$ was considered strong hydrolytic activity, 3 to $5 \mathrm{~mm}$ moderate activity and 1 to $2 \mathrm{~mm}$ weak activity.

Siderophore production. The universal method of Schwyn \& Neilands (1987) was employed with some modifications. Briefly, isolates were grown in irondeficient MM9 broth for $48 \mathrm{~h}$ at $30^{\circ} \mathrm{C}$ under constant agitation at $95 \mathrm{rpm}$. For isolates not able to grow in this medium, a supplement of l-ornithine and l-lysine was added at $0.5 \%$, followed by incubation at $30^{\circ} \mathrm{C}$ for a further $30 \mathrm{~h}$. Afterwards, the broth was used in 2 differ- ent treatments. In one treatment it was plated directly onto chrome azurol S agar (CAS); in the other it was plated first on iron-deficient MM9 agar $\left(30^{\circ} \mathrm{C}\right.$ for $\left.48 \mathrm{~h}\right)$ followed by transfer onto CAS agar. All media employed were supplemented with $2.5 \% \mathrm{NaCl}$. Incubation in CAS agar was at 26 to $27^{\circ} \mathrm{C}$ for up to $72 \mathrm{~h}$ and orange halos around colonies were measured at 48 and $72 \mathrm{~h}$ by measuring the diameter of the halo around each colony and subtracting from the colony diameter to give the relative activity $(\mathrm{mm})$. Siderophore production was considered positive when the halo diameter divided by the colony diameter exceeded 1.3 (Amaro et al. 1990).

Hemolytic activity. Commercial blood agar medium (Bioxon) was enriched with $5 \%$ sterile sheep blood and $2.5 \% \mathrm{NaCl}$. The bacteria were streaked onto the medium and incubated for $72 \mathrm{~h}$ at $30^{\circ} \mathrm{C}$. Yellow halos of hemolysis were recorded and categorized qualitatively as non-existent $(-)$, weak $(+)$, moderate $(++)$, high $(+++)$, and very high $(++++)$.

Statistics. Results were statistically analyzed for normality and differences were estimated by an analysis of variance (ANOVA) test while multiple comparisons were done using Duncan or Tukey tests (Zar 1999).

\section{RESULTS}

\section{Isolate characterization and identification}

All isolates analyzed were identified as belonging to the genus Vibrio, since they were Gram-negative rods, motile, oxidase-positive, fermented glucose, were sensitive to the vibriostatic agent O/129, and utilized D-mannitol as sole source of carbon (Baumann \& Schubert 1984).

All isolates were arginine dihydrolase-negative, lysine and ornithine decarboxylase-positive. Isolates PN9801, IPL8, PL96-11-6, Z2, 10 MZ, Z1, 11 MZ, Na, Z3, Ea, 1A, STD3-131 and STD3-1002 were identified as typical Vibrio harveyi (citrate-variable, negative for Voges-Proskauer; positive growth with $8 \% \mathrm{NaCl}$ and negative with $0 \% \mathrm{NaCl}$ ). Isolate $\mathrm{M} 1$ was identified as a D-glucosamine-positive $V$. harveyi. Isolate AP9701 was identified as $V$. vulnificus (positive growth in 0 and $8 \%$ $\mathrm{NaCl}$, citrate-positive). Isolates $\mathrm{ML}$ and $2 \mathrm{Mz}$ were identified as $V$. alginolyticus (growth at $8 \% \mathrm{NaCl}$, citrate- and Voges-Proskauer-positive). All were luminescent except isolates $V$. harveyi STD3-1002 and V. alginolyticus $2 \mathrm{MZ}$ and ATCC 17749.

\section{Pathogenicity}

Significant differences were observed in the mortalities of Artemia franciscana nauplii exposed to several 
luminous isolates compared to the controls (Fig. 2). The bacterial isolates that caused significant mortalities $(p<0.05)$ were 1A and STD3-131 (Fig 2a), Na (Fig. 2b), $Z_{1}$ and $M_{1}$ (Fig. 2c), $Z_{2}$ and $Z_{3}$ (Fig. 2d), AP9701 and PN9801 (Fig. 2e). The sixth experiment (Fig. 2f) generally confirmed the reproducibility of the results regarding Isolates $Z_{2}, P N 9801$ and $M_{1}$, even though the mortality percentages obtained were somewhat higher. The highest mortalities were obtained with Isolates $\mathrm{M}_{1}, \mathrm{PN} 9801$ and $\mathrm{Z}_{2}$ (Table 2). No relation was observed between the isolation source of the strains and their pathogenicity to Artemia nauplii. Only 2 strains (STD3131 and PN9801) out of 6 isolated from diseased shrimp caused significant mortalities $(p<0.05)$.
Bacteria were inoculated at a final density of $10^{5}$ to $10^{6} \mathrm{CFU} \mathrm{ml}^{-1}$, and the bioencapsulation varied from a maximum of $2.00 \times 10^{3} \mathrm{CFU}$ nauplius ${ }^{-1}$ to a minimum of $4.00 \times 10^{1} \mathrm{CFU}$ nauplius ${ }^{-1}$ (Table 2). No significant correlation was observed between the mean density of bacteria ingested by the Artemia franciscana nauplii (bioencapsulated) and mean naupliar mortality (Pearson product-moment test after logarithmic base-10 transformation, $\mathrm{r}=-0.210, \mathrm{p}=0.326, \mathrm{n}=24$ ). Nor was there any significant correlation between the mean inoculation density of bacteria and the bioencapsulation of bacteria by the Artemia nauplii (Pearson product-moment test after logarithmic base-10 transformation, $\mathrm{r}=0.336, \mathrm{p}=0.108, \mathrm{n}=24$ ).
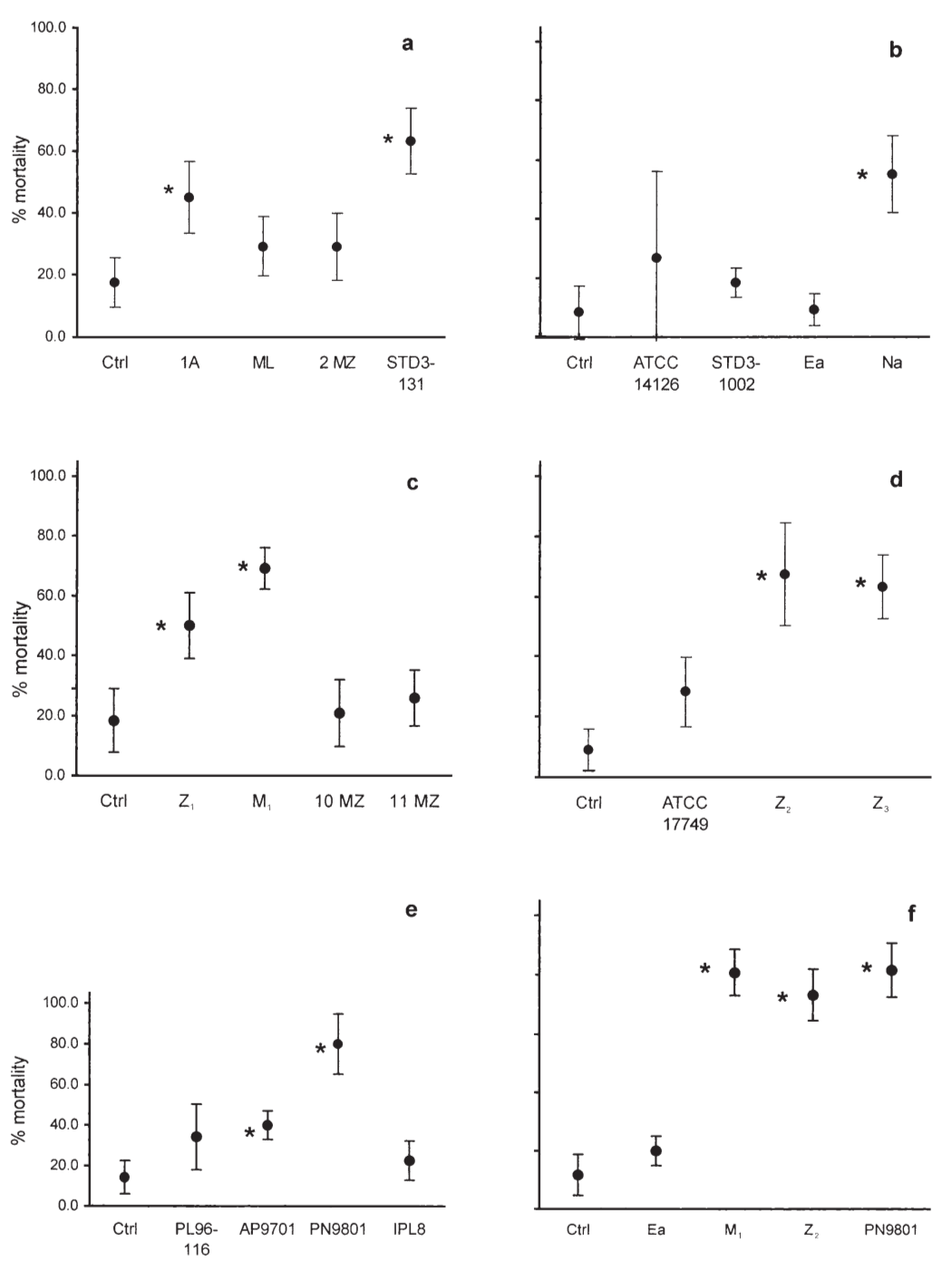

Fig. 2. Artemia franciscana. Percent mortality of nauplii exposed to specified bacterial strains (abbreviated as in Table 1; ATCC 17749: Reference Strain Vibrio alginolyticus; Ctrl: control). Mean mortalities with $95 \%$ confidence interval are shown for $48 \mathrm{~h}$ post-exposure. Treatments with asterisks are statisticlly different from the control $(p<0.05)$. (a-e) Challenges with different strains;

(f) challenge with the 3 most virulent strains and a non-virulent strain (Ea)

\section{Cell surface hydrophobicity}

With the SAT test, all the isolates were classified as weakly hydrophobic (ranging from 2.5 to $4.0 \mathrm{M}$ : Table 3 ). In contrast, the BATH assay indicated that all the isolates were strongly hydrophobic (> 50\% partitioning). The highest degree of hydrophobicity (> $80 \%$ ) was observed for Isolates STD3-131, $Z_{1}, Z_{2}$, $\mathrm{Z}_{3}$ and PL96-11-6. No significant correlation was observed between the mean hydrophobicity of the isolates by either method and mean naupliar mortalities (SAT method: Spearman test, $\mathrm{r}=-0.0143, \mathrm{p}=0.952, \mathrm{n}=14 ; \mathrm{BATH}$ method: Spearman test, $\mathrm{r}=-0.0217$, $\mathrm{p}=0.928, \mathrm{n}=18$ ).

\section{Enzymatic activity}

Most of the isolates produced lipases, phospholipases and proteases at $48 \mathrm{~h}$, except Isolates $10 \mathrm{MZ}$ and $11 \mathrm{MZ}$, which did not produce proteases (Table 3), and Isolate $2 \mathrm{MZ}$, that produced proteases only. In contrast, few tested isolates produced gelatinases (Vibrio harveyi ATCC 14126, Isolates 1A, ML, $10 \mathrm{MZ}$, PL96-11-6 and IPL8). Phospholipases were secreted until $96 \mathrm{~h}$ and they showed the highest production compared with other enzymes (data not shown). The production of exoenzymes was rated as moderate to strong in most isolates, and it generally increased in time up to $96 \mathrm{~h}$ (data not shown). In general terms, V. harveyi Isolates 1A, STD3- 
Table 2. Artemia franciscana. Challenge density of Vibrio bacteria, number ingested and percent mortality of challenged nauplii in Expts 1 to 6 (a to $\mathrm{f}$ in Fig. 2). ${ }^{*}$ Significantly different from respective controls $(p<0.05)$

\begin{tabular}{|c|c|c|c|c|}
\hline Strain & $\begin{array}{l}\text { Inoculation } \\
\text { density } \\
\text { of bacteria } \\
\left(\log \mathrm{CFU} \mathrm{m}{ }^{-1}\right)\end{array}$ & $\begin{array}{c}\text { Density of } \\
\text { bacteria } \\
\text { bioencapsulated } \\
\left(\log \text { CFU nauplius }{ }^{-1}\right)\end{array}$ & $\begin{array}{l}\text { Mean } \\
\text { mortality } \\
(\%)\end{array}$ & $\mathrm{SE}$ \\
\hline \multicolumn{5}{|l|}{ Expt 1} \\
\hline Control & & & 12.5 & 2.50 \\
\hline $1 \mathrm{~A}$ & 6.28 & 3.03 & $45.0^{*}$ & 5.92 \\
\hline $\mathrm{ML}$ & 6.37 & 3.20 & 29.2 & 4.90 \\
\hline $2 \mathrm{MZ}$ & 6.24 & 3.32 & 29.2 & 5.54 \\
\hline STD3-131 & 6.26 & 1.97 & $63.3^{*}$ & 5.43 \\
\hline \multicolumn{5}{|l|}{ Expt 2} \\
\hline Control & & & 8.3 & 4.59 \\
\hline V. harveyi ${ }^{\mathrm{a}}$ & 5.89 & 0.60 & 12.0 & 4.36 \\
\hline STD3-1002 & 6.06 & 1.00 & 18.3 & 2.47 \\
\hline Ea & 6.13 & 2.10 & 9.2 & 2.71 \\
\hline $\mathrm{Na}$ & 5.91 & 2.08 & $55.0^{*}$ & 6.58 \\
\hline \multicolumn{5}{|l|}{ Expt 3} \\
\hline Control & & & 18.3 & 5.43 \\
\hline $\mathrm{Z}_{1}$ & 5.76 & 2.24 & $50.0^{*}$ & 5.63 \\
\hline $\mathrm{M}_{1}$ & 4.93 & 1.56 & $69.2^{*}$ & 3.52 \\
\hline $10 \mathrm{MZ}$ & 5.66 & 2.31 & 20.8 & 5.69 \\
\hline $11 \mathrm{MZ}$ & 5.82 & 2.66 & 25.8 & 4.73 \\
\hline \multicolumn{5}{|l|}{ Expt 4} \\
\hline Control & & & 9.2 & 3.52 \\
\hline V. alginolyticus ${ }^{b}$ & 5.75 & 0.85 & 28.3 & 5.87 \\
\hline $\mathrm{Z}_{2}$ & 5.73 & 1.70 & $67.5^{*}$ & 8.73 \\
\hline $\mathrm{Z}_{3}$ & 6.18 & 1.78 & $63.6^{*}$ & 5.43 \\
\hline \multicolumn{5}{|l|}{ Expt 5} \\
\hline Control & & & 14.2 & 4.17 \\
\hline AP9701 & 5.40 & 1.45 & $38.7^{*}$ & 5.54 \\
\hline PL96-11-6 & 5.94 & 1.04 & 34.2 & 8.31 \\
\hline PN9801 & 6.58 & 2.20 & $80.0^{*}$ & 7.53 \\
\hline IPL8 & 6.64 & 2.66 & 22.5 & 4.96 \\
\hline \multicolumn{5}{|l|}{ Expt 6} \\
\hline Control & & & 11.7 & 3.57 \\
\hline Ea & 6.10 & 2.91 & 20.0 & 2.58 \\
\hline M1 & 6.13 & 1.04 & $73.3^{*}$ & 3.96 \\
\hline PN9801 & 6.79 & 1.72 & $80.8^{*}$ & 4.41 \\
\hline $\mathrm{Z}_{2}$ & 5.95 & 0.90 & $81.7^{*}$ & 4.59 \\
\hline \multicolumn{5}{|l|}{ aATCC 14126} \\
\hline bATCC 17749 & & & & \\
\hline
\end{tabular}

\section{Siderophore production}

Of all the isolates analyzed, 11 $(61.1 \%)$ were considered to produce siderophores as they had halo/colony diameter ratios higher than 1.3 (Table 3 ) at $72 \mathrm{~h}$ of incubation. Exceptions were Isolates Ea, Z , ML, 10Mz, PL96-11-6, 2Mz, and Vibrio harveyi ATCC 14126. A significant correlation was found between percent mortality of nauplii and siderophore production as measured by halo diameter (Spearman test, $\mathrm{r}=0.561$, $\mathrm{p}=0.019, \mathrm{n}=17$ ).

\section{Hemolytic activity}

Hemolytic activity was difficult to evaluate since no clear halo border was observed around the colonies of the isolates tested. Therefore the activity was coded with qualitative parameters (weak, moderate, high or very high). Considering this rough interpretation, no relationship was observed between percentage mortality of nauplii and hemolytic activity (Table 3 ). The highest hemolytic activities were observed in Vibrio harveyi ATCC 14126 and IPL8, which did not produce significant mortalities (Fig. 2e), while the 3 most virulent isolates $\left(\mathrm{M}_{1}, \mathrm{Z}_{2}\right.$ and $\left.\mathrm{PN9801}\right)$ showed high to weak activities (Table 3).

\section{DISCUSSION}

We identified 14 isolates as Vibrio harveyi on the basis of phenotypic characteristics, although some strains showed atypical test results that are not

$131, N a, M_{1}, Z_{1}, Z_{2}, Z_{3}$ and had the highest enzyme production at $48 \mathrm{~h}$ incubation.

A significant positive correlation was obtained between protease production and percentage mortality of nauplii (Pearson product-moment test, $r=0.550$, $\mathrm{p}=0.018, \mathrm{n}=18$ ) and between mortality and the production of phospholipases at $48 \mathrm{~h}$ (Spearman test, $\mathrm{r}=0.566, \mathrm{p}=0.0141, \mathrm{n}=18$ ). No correlation was observed between percentage of naupliar mortality and production of gelatinase at $48 \mathrm{~h}$ (Spearman test, $\mathrm{r}=-0.423, \mathrm{p}=0.079, \mathrm{n}=18$ ) and of lipases at $48 \mathrm{~h}$ (Spearman test, $\mathrm{r}=-0.0917, \mathrm{p}=0.711, \mathrm{n}=18$ ). unusual in isolates from seawater and shrimp culture systems (Karunasagar et al. 1994, Liu et al. 1996a,b, Alvarez et al. 1998).

The bioencapsulation of bacteria results presented here and elsewhere (Gomez-Gil et al. 1998, Makridis et al. 2000, Roque et al. 2000, Verschuere et al. 2000) suggest that Artemia franciscana nauplii have a maximum capacity for bioencapsulation (ingestion) of bacterial cells ranging from $10^{2}$ to $10^{4} \mathrm{CFU}$ nauplius ${ }^{-1}$, independent of the bacterial density to which they are exposed $\left(10^{6}\right.$ to $\left.10^{8} \mathrm{CFU} \mathrm{ml} \mathrm{m}^{-1}\right)$ but dependent on the bacterial strain employed. The density of bacteria 
bioencapsulated by the A. nauplii did not significantly correlate with their mortality. This suggests that pathogenic characteristics of each isolate were more important than the density ingested, as demonstrated also by Gomez-Gil et al. (1998) and Verschuere et al. (2000). High naupliar mortalities up to $100 \%$ have been observed with 2 strains of Vibrio parahaemolyticus and $V$. alginolyticus (Rico-Mora \& Voltolina 1995) and 1 strain of $V$. proteolyticus (Verschuere et al. 2000). In the present study, the maximum mortality observed was $82 \%$ with Strain $Z_{2}$. Such differences have also been found in bath challenges with penaeid shrimps. Variability is possibly connected with shrimp species tested (Vera et al. 1992), doses used, time of exposure, age of the shrimp (Jun \& Huai-Shu 1998) or pathogenic factors of the strains employed (Pena et al. 1993, Gomez-Gil et al. 1998). Variation in virulence for penaeid shrimp larvae has also been observed in $V$. harveyi strains isolated from different geographical regions and organisms (Lavilla-Pitogo et al. 1990, Pizzuto \& Hirst 1995, Abraham et al. 1997). In the present study, $<50 \%$ of the strains isolated from diseased shrimp caused significant mortality in A. franciscana nauplii. Therefore, no correlation was observed between isolation source and percent mortality, and pathogenicity is not guaranteed when strains are isolated from diseased crustaceans. It would be interest- ing to challenge shrimp larvae with this set of strains, but a reproducible challenge protocol for penaeid larvae is still not available.

Exoenzyme production, cell surface hydrophobicity and toxin production have been considered virulence factors for some pathogenic bacteria (Lee 1995, Balebona et al. 1998). Theoretically, hydrophobic isolates have high affinity for and can easily colonize host tissues, ensuring survival and reproduction. All the isolates analyzed exhibited weak hydrophobicity by the SAT assay, possibly indicating a lack of salting-out agents. Indeed, weak to moderate hydrophobicity was found in several Vibrio harveyi reference strains (Lee \& Yii 1996) and in V. harveyi isolates pathogenic from clams (Borrego et al. 1996). Low hydrophobicity has also been found in $V$. fischeri, $V$. nereis, $V$. harveyi and $V$. anguillarum isolated from diseased sea bream (Balebona et al. 1995). In contrast to results obtained with the SAT method, results with the BATH test showed strong hydrophobicity in all the isolates tested. Lack of correlation between SAT and BATH test results was also observed by Santos et al. (1990) and by Lee \& Yii (1996). Lack of correlation between pathogenicity and hydrophobicity has also been reported by Romalde et al. (1990), who concluded that cell surface properties were not good criteria for estimating pathogenicity of the fish pathogen Yersinia ruckerii. Difficul-

Table 3. Vibrio spp. Cell surface hydrophobicity, hydrolytic and hemolytic activities, and siderophore production of isolates from shrimp culture systems. SAT: salt-aggragation test; BATH: bacterial adhesion to hydrocarbons test. Hydrophobicity: w = weak; $>50 \%$ partitioning $=$ strong. Hydrolytic activities: $\mathrm{s}=$ strong; $\mathrm{m}=$ moderate $; \mathrm{w}=$ weak; $\mathrm{nd}=$ no data. Siderophore production: $+=$ positive acivity $;-=$ negative activity. Hemolytic activity: $+=$ weak $_{i}++=$ moderate $^{++++}=$high $_{i}++++=$ very high

\begin{tabular}{|c|c|c|c|c|c|c|c|c|c|c|c|c|}
\hline \multirow[t]{3}{*}{ Strain } & \multicolumn{2}{|c|}{ Hydrophobicity } & \multicolumn{7}{|c|}{ Hydrolytic activities (diam., mm) } & \multirow{2}{*}{\multicolumn{3}{|c|}{$\begin{array}{c}\text { Siderophore } \\
\text { pemolytic } \\
\text { production activity }\end{array}$}} \\
\hline & \multirow{2}{*}{\multicolumn{2}{|c|}{ 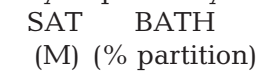 }} & \multirow{2}{*}{$\begin{array}{l}\text { Protease } \\
(10 \mu \mathrm{l})\end{array}$} & \multicolumn{2}{|c|}{ Gelatinase } & \multicolumn{2}{|c|}{ Lipase } & \multicolumn{2}{|c|}{ Phospholipase } & & & \\
\hline & & & & $24 \mathrm{~h}$ & $48 \mathrm{~h}$ & $24 \mathrm{~h}$ & $48 \mathrm{~h}$ & $24 \mathrm{~h}$ & $48 \mathrm{~h}$ & $72 \mathrm{~h}$ & Ratio & $72 \mathrm{~h}$ \\
\hline \multicolumn{13}{|l|}{ V. harveyi } \\
\hline ATCC 14126 & $4.0(\mathrm{w})$ & 76.0 & 0 & $3.0(\mathrm{~m})$ & $4.5(\mathrm{~m})$ & $1.5(\mathrm{w})$ & $3.0(\mathrm{~m})$ & $2.0(\mathrm{w})$ & 3.0 & 0 & $1.00(-)$ & ++++ \\
\hline $1 \mathrm{~A}$ & $4.0(\mathrm{w})$ & 77.1 & $5.0(\mathrm{~m})$ & $1.5(\mathrm{w})$ & $1.5(\mathrm{w})$ & $1.5(\mathrm{w})$ & $3.0(\mathrm{~m})$ & $2.0(\mathrm{w})$ & $2.0(\mathrm{w})$ & 2.0 & $1.67(+)$ & + \\
\hline STD3-131 & $4.0(\mathrm{w})$ & 62.6 & $1.0(\mathrm{w})$ & 0 & 0 & $1.0(\mathrm{w})$ & $2.0(\mathrm{w})$ & $4.0(\mathrm{~m})$ & 7.0 & 1.5 & $1.50(+)$ & ++ \\
\hline STD3-1002 & $2.0(\mathrm{w})$ & 84.9 & $2.0(\mathrm{w})$ & 0 & 0 & 0 & $3.0(\mathrm{~m})$ & $2.0(\mathrm{w})$ & 3.0 & 0.6 & $1.60(+)$ & +++ \\
\hline $\mathrm{Ea}$ & $4.0(\mathrm{w})$ & 70.1 & $1.0(\mathrm{w})$ & 0 & 0 & $2.0(w)$ & $4.0(\mathrm{~m})$ & $2.0(\mathrm{w})$ & 3.0 & 0 & $1.00(-)$ & + \\
\hline $\mathrm{Na}$ & $3.0(w)$ & 78.6 & $4.0(\mathrm{~m})$ & 0 & 0 & $3.0(\mathrm{~m})$ & $4.0(\mathrm{~m})$ & $3.0(\mathrm{~m})$ & 6.0 & 2.0 & $1.67(+)$ & nd \\
\hline $\mathrm{M}_{1}$ & $4.0(\mathrm{w})$ & 64.4 & $3.0(\mathrm{~m})$ & 0 & 0 & $2.0(w)$ & $3.0(\mathrm{~m})$ & $3.0(\mathrm{~m})$ & 5.0 & 2.0 & $1.67(+)$ & +++ \\
\hline $10 \mathrm{MZ}$ & $2.5(\mathrm{w})$ & 79.1 & 0 & 0 & $1.5(\mathrm{w})$ & 0 & $4.0(\mathrm{~m})$ & 0 & 0 & 0 & $1.00(-)$ & ++ \\
\hline $11 \mathrm{MZ}$ & $2.5(w)$ & 65.0 & 0 & 0 & 0 & $1.5(\mathrm{w})$ & $3.0(\mathrm{~m})$ & 0 & 3.0 & 2.0 & $1.67(+)$ & + \\
\hline $\mathrm{Z}_{1}$ & $3.0(\mathrm{w})$ & 84.8 & $4.0(\mathrm{~m})$ & 0 & 0 & $2.0(w)$ & $3.0(\mathrm{~m})$ & $3.0(\mathrm{~m})$ & 6.0 & 1.5 & $1.50(+)$ & +++ \\
\hline $\mathrm{Z}_{2}$ & $2.5(\mathrm{w})$ & 83.7 & $4.0(\mathrm{~m})$ & 0 & 0 & $2.0(w)$ & $3.0(\mathrm{~m})$ & $3.0(\mathrm{~m})$ & 6.0 & 0.6 & $1.20(-)$ & +++ \\
\hline $\mathrm{Z}_{3}$ & $2.5(w)$ & 87.4 & $4.0(\mathrm{~m})$ & 0 & 0 & $2.0(w)$ & $3.0(\mathrm{~m})$ & $3.0(\mathrm{~m})$ & 5.0 & 1.0 & $1.33(+)$ & ++ \\
\hline PN9801 & nd & 68.8 & $2.0(\mathrm{w})$ & 0 & 0 & $2.0(\mathrm{w})$ & 3.0 (m) & $2.0(\mathrm{w})$ & 5.0 & 2.5 & $1.83(+)$ & + \\
\hline PL96-11-6 & nd & 82.8 & $1.0(\mathrm{w})$ & 0 & $1.5(\mathrm{w})$ & 0 & $1.0(\mathrm{w})$ & $1.0(\mathrm{w})$ & 5.0 & 0.6 & $1.20(-)$ & +++ \\
\hline IPL8 & nd & 73.2 & $3.0(\mathrm{~m})$ & 0 & $1.5(w)$ & 0 & $1.0(w)$ & $2.0(w)$ & 6.0 & 1.5 & $4.00(+)$ & ++++ \\
\hline \multicolumn{13}{|l|}{ V.alginolyicus } \\
\hline ML & $4.0(\mathrm{w})$ & 52.8 & $1.0(\mathrm{w})$ & $1.5(\mathrm{w})$ & $1.5(\mathrm{w})$ & $1.5(\mathrm{w})$ & $3.0(\mathrm{~m})$ & $2.0(\mathrm{w})$ & 3.0 & 0 & $1.00(-)$ & ++ \\
\hline $2 \mathrm{MZ}$ & $4.0(w)$ & 65.3 & $2.0(\mathrm{w})$ & 0 & 0 & 0 & 0 & 0 & 0 & 0 & $1.00(-)$ & +++ \\
\hline \multicolumn{13}{|l|}{ V. vulnificus } \\
\hline AP9701 & nd & 68.9 & $1.0(\mathrm{w})$ & 0 & 0 & 0 & $1.0(\mathrm{w})$ & $2.0(\mathrm{w})$ & 5.0 & 1.5 & $1.75(+)$ & + \\
\hline
\end{tabular}


ties in comparison of experimental results between laboratories include the necessity of standardizing the assay conditions (e.g. growth medium, temperature, initial cell density, etc.) (Santos et al. 1990) and the growth phase of the bacterial cells used. For example, exponential-phase cells adhere better than stationaryphase cells (Vazquez-Juarez et al. 1994).

Production of extracellular enzymes by bacterial fish pathogens has been widely observed (Amaro et al. 1992, Esteve et al. 1995, Biosca \& Amaro 1996, Balebona et al. 1998, Alcaide et al. 1999, Linkous \& Oliver 1999), but the role of these products in pathogenesis is still not clear. Several isolates studied here showed moderate to strong activity for proteases and phospholipases, and these activities gave significant positive correlation with naupliar mortality. Other authors have also observed high enzyme activity in virulent Vibrio harveyi strains isolated from mollusks (Borrego et al. 1996) and from shrimps and fishes (Liu et al. 1996b, Montero \& Austin 1999, Zhang \& Austin 2000).

Extracellular protease production was positively correlated with naupliar mortality in this study, and modes of action for these strains could be similar to those of several vibrios and aeromonads in which proteases have been implicated to play a significant role in their virulence to marine organisms (Kothary \& Kreger 1987, Nottage \& Birkbeck 1987, Norqvist et al. 1990, Nieto \& Ellis 1991, Lee et al. 1997, Liu et al. 1997, Arnesen \& Eggset 1999, Harris \& Owens 1999, Liu \& Lee 1999). Proteases secreted by some strains of Vibrio parahaemolyticus and $V$. alginolyticus and several strains of $V$. harveyi act by destroying enzymatic haemolymph clotting in shrimp (Bing et al. 1993, Lee et al. 1997, 1999).

Phospholipase was also positively correlated with naupliar mortality, and is another enzyme considered to be a virulence factor due to its capability for lysing fish cells (Lee \& Ellis 1990). This activity has been demonstrated for some Vibrio harveyi strains that lyse rainbow trout erythrocytes (Zhang \& Austin 1999), and the genes responsible for this have been characterized (Zhang et al. 2000).

Siderophore production was significantly correlated to naupliar mortality, and it is considered to be an essential virulence factor in some species (Wolf \& Crosa 1986, Amaro et al. 1990, Ratledge \& Dover 2000) although not clearly so in others (Owens et al. 1996, Pedersen et al. 1997). Other studies reported that virulent strains of Photobacterium damselae (formerly Vibrio damsela) showed siderophore production values very similar to those obtained herein, and were also independent of source or serogroup (Owens et al. 1996, Fouz et al. 1997).

In summary, virulence of the luminous bacterial isolates studied was more related to the production of particular exoenzymes (exotoxins?) than to colonization factors. In spite of this apparent trend, we accept that pathogenesis is a multifactor process and that a single factor is unlikely to be the sole determinant of virulence for any individual bacterial isolate.

Acknowledgements. Part of this study was funded by CONACYT Project J-28344. We thank Celia Lavilla-Pitogo and Professor Jean Swings for providing bacterial strains, Ivone Giffard for collecting some of the isolates, and Dr. Manuel L. Lemos for the Vibrio anguillarum 775 strain. Thanks also to Carmen Bolán, Lorenzo Zamorano, and Alicia Parra for their technical assistance.

\section{LITERATURE CITED}

Abraham TJ, Manley R (1995) Luminous and non-luminous Vibrio harveyi associated with shell disease in cultured Penaeus indicus. J Aquacult Trop 10:273-276

Abraham TJ, Manley R, Palaniappan R, Dhevendaran K (1997) Pathogenicity and antibiotic sensitivity of luminous Vibrio harveyi isolated from diseased penaeid shrimp. J Aquacult Trop 12:1-8

Alcaide E, Amaro C, Todolí R, Oltra R (1999) Isolation and characterization of Vibrio parahaemolyticus causing infection in Iberian toothcarp Aphanius iberus. Dis Aquat Org 35:77-90

Alsina M, Blanch AR (1994) A set of keys for biochemical identification of environmental Vibrio species. J Appl Bacteriol 76:79-85

Alvarez JD, Austin B, Austin AM, Reyes H (1998) Vibrio harveyi: a pathogen of penaeid shrimps and fish in Venezuela. J Fish Dis 21:313-316

Amaro C, Aznar R, Alcaide E, Lemos ML (1990) Iron-binding compounds and related outer membrane proteins in Vibrio cholerae non-O1 strains from aquatic environments. Appl Environ Microbiol 56:2410-2416

Amaro C, Biosca EG, Esteve C, Fouz B, Toranzo A (1992) Comparative study of phenotypic and virulence properties in Vibrio vulnificus biotype 1 and 2 obtained from a European eel farm experiencing mortalities. Dis Aquat Org 13: 29-35

Arnesen JA, Eggset G (1999) Isolation and characterization of two extracellular metaloproteases from Aromonas salmonicida ssp. salmonicida. J Fish Dis 22:35-43

Balebona MC, Morinigo MA, Faris A, Krovacek K, Maansson I, Bordas MA, Borrego JJ (1995) Influence of salinity and $\mathrm{pH}$ on the adhesion of pathogenic Vibrio strains to Sparus aurata skin mucus. Aquaculture 132:113-120

Balebona MC, Andreu M, Bordas M, Zorrilla I, Morinigo MA, Borrego JJ (1998) Pathogenicity of Vibrio alginolyticus for cultured gilt-head sea bream (Sparus aurata L.). Appl Environ Microbiol 64:4269-4275

Baticados MCL, Lavilla-Pitogo CR, Cruz-Lacierda ER, Pena LD, Sunaz NA (1990) Studies on the chemical control of luminous bacteria Vibrio harveyi and Vibrio splendidus isolated from diseased Penaeus monodon larvae and rearing water. Dis Aquat Org 9:133-139

Baumann P, Schubert RHW (1984) Vibrionaceae. In: Krieg NR, Holt GJ (eds) Bergey's manual of systematic bacteriology. Williams \& Wilkins, Baltimore, PA, p 516-550

Bing X, Huai-Shu X, Wishang J (1993) Pathogens and pathogenicity to Penaeus orientalis Kishinouye. Acta Oceanol Sin 3:297-304

Biosca EG, Amaro C (1996) Toxic and enzymatic activities of 
Vibrio vulnificus biotype 2 with respect to host specificity. Appl Environ Microbiol 62:2331-2337

Borrego JJ, Luque A, Castro D, Santamaria JA, MartinezManzanares E (1996) Virulence factors of Vibrio P1, the causative agent of brown ring disease in the manila clam, Ruditapes philippinarum. Aquat Living Resour 9:125-136

Campbell R, Adams A, Tatner MF, Chair M, Sorgeloos P (1993) Uptake of Vibrio anguillarum vaccine by Artemia salina as a potential oral delivery system to fish fry. Fish Shellfish Immunol 3:451-459

Chair M, Romdhane M, Dehasque M, Nelis H, De Leenheer AP, Sorgeloos P (1991) Live-food mediated drug delivery as a tool for disease treatment in larviculture. 2. A case study with European seabass. In: Lavens P, Sorgeloos P, Jaspers E, Ollevier F (eds) LARVI ' 91, European Aquaculture Society, Genf, p 412-414

Chair M, Dehasque M, Van Poucke S, Nelis H, Sorgeloos P, De Leenheer AP (1994) An oral challenge for turbot larvae with Vibrio anguillarum. Aquac Int 2:270-272

Cowan ST, Steel KJ, Barrow GI, Feltham RKA (1993) Cowan and Steel's manual for the identification of medical bacteria. Cambridge University Press, Cambridge

Diggles BK, Moss GA, Carson J, Anderson CD (2000) Luminous vibriosis in rock lobster Jasus verreauxi (Decapoda: Palinuridae) phyllosoma larvae associated with infection by Vibrio harveyi. Dis Aquat Org 43:127-137

Esteve C, Amaro C, Biosca EG, Garay E (1995) Biochemical and toxigenic properties of Vibrio furnissii isolated from a European eel farm. Aquaculture 132:81-90

Fouz B, Biosca EG, Amaro C (1997) High affinity iron-uptake systems in Vibrio damsela: role in the acquisition of iron from transferrin. J Appl Microbiol 82:157-167

Gherna LR (1994) Culture preservation. In: Gerhardt P, Murray RGE, Wood WA, Krieg NR (eds) Methods for general and molecular bacteriology. American Society for Microbiology, Washingtion, DC, p 278-292

Gomez-Gil B, Herrera-Vega MA, Abreu-Grobois FA, Roque A (1998) Bioencapsulation of two different Vibrio species in nauplii of the brine shrimp (Artemia franciscana). Appl Environ Microbiol 64:2318-2322

Harris LJ, Owens L (1999) Production of exotoxins by two luminous Vibrio harveyi strains known to be primary pathogens of Penaeus monodon larvae. Dis Aquat Org 38: $11-22$

Jiravanichpaisal P, Miyazaki T, Limsuwan C (1994) Histopathology, biochemistry, and pathogenicity of Vibrio harveyi infecting black tiger prawn Penaeus monodon. J Aquat Anim Health 6:27-35

Joosten PHM, Aviles-Trigueros M, Sorgeloos P, Rombout J (1995) Oral vaccination of juvenile carp (Cyprinus carpio) and gilthead seabream (Sparus aurata) with bioencapsulated Vibrio anguillarum bacterin. Fish Shellfish Immunol 5:289-299

Jun LI, Huai-Shu X (1998) Isolation and biological characteristics of Vibrio harveyi affecting hatchery-reared Penaeus chinensis larvae. Oceanol Limnol Sin 29:353-361

Karunasagar I, Pai R, Malathi GR (1994) Mass mortality of Penaeus monodon larvae due to antibiotic-resistant Vibrio harveyi infection. Aquaculture 128:203-209

Kothary MH, Kreger AS (1987) Purification and characterization of an elastolytic protease of Vibrio vulnificus. J Gen Microbiol 133:1783-1791

Lavilla-Pitogo CR (1995) Bacterial diseases of penaeid shrimps: an Asian view. In: Shariff M, Arthur JR, Subasinghe RP (eds) Diseases in Asian aquaculture II. Fish Health Section, Asian Fisheries Society, Manila, p 107-121
Lavilla-Pitogo CR, Baticados MCL, Cruz-Lacierda ER, Pena LD (1990) Occurrence of luminous bacterial disease of Penaeus monodon larvae in the Philippines. Aquaculture 91:1-13

Lee KK (1995) Pathogenesis studies on Vibrio alginolyticus in the grouper, Epinephelus malabaricus, Bloch et Schneider. Microb Pathog 19:39-48

Lee KK, Ellis AE (1990) Glycerophospholipid:cholesterol acyltransferase complexed with lipopolysaccharide (LPS) is a major lethal exotoxin and cytolysin of Aeromonas salmonicida: LPS stabilizes and enhances toxicity of the enzyme. J Bacteriol 172:5382-5393

Lee KK, Yii KC (1996) A comparison of three methods for assaying hydrophobicity of pathogenic Vibrios. Lett Appl Microbiol 23:343-346

Lee KK, Chen FR, Yu RR, Yang TI, Liu PC (1997) Effects of extracellular products of Vibrio alginolyticus on penaeid shrimp plasma components. Lett Appl Microbiol 25:98-100

Lee KK, Chen YL, Liu PC (1999) Hemostasis of tiger prawn Penaeus monodon affected by Vibrio harveyi, extracellular products, and a toxic cysteine protease. Blood Cells Mol Dis 25:180-192

Lindhal MA, Faris A, Wadstroom T, Herten S (1981) A new test based on 'salting out' to measure relative surface hydrophobicity of bacterial cells. Biochim Biophys Acta 667:471-476

Linkous DA, Oliver JD (1999) Pathogenesis of Vibrio vulnificus. FEMS Microbiol Lett 174:207-214

Liu PC, Lee KK (1999) Cysteine protease is a major exotoxin of pathogenic luminous Vibrio harveyi in the tiger prawn, Penaeus monodon. Lett Appl Microbiol 28:428-430

Liu PC, Lee KK, Yii KC, Kou GH, Chen SN (1996a) Isolation of Vibrio harveyi from diseased kuruma prawns Penaeus japonicus. Curr Microbiol 33:129-132

Liu PC, Lee KK, Chen SN (1996b) Pathogenicity of different isolates of Vibrio harveyi in tiger prawn, Penaeus japonicus. Lett Appl Microbiol 22:413-416

Liu PC, Lee KK, Tu CC, Chen SN (1997) Purification and characterization of a cysteine protease produced by pathogenic luminous Vibrio harveyi. Curr Microbiol 35:32-39

MacFaddin JF (1990) Pruebas bioquímicas para la identificación de bacterias de importancia clínica. Editorial Médica Panamericana, Mexico City

Makridis P, Fjellheim AJ, Skjermo J, Vadstein O (2000) Control of the bacterial flora of Brachionis plicatilis and Artemia franciscana by incubation in bacterial suspensions. Aquaculture 185:207-218

Mohney LL, Lightner DV, Williams RR, Bauerlein M (1990) Bioencapsulation of therapeutic quantities of the antibacterial Romet-30 in nauplii of the brine shrimp Artemia and in the nematode Panagrellus redivivus. J World Aquacult Soc 21:186-191

Montero AB, Austin B (1999) Characterization of extracellular products from an isolate of Vibrio harveyi recovered form diseased post-larval Penaeus vannamei (Bonne). J Fish Dis 22:377-386

Morita J, Suzuki S, Kusuda R (1994) Protease production profiles of the fish pathogen Listonella anguillara based on substrate specificities. Fish Sci 60:741-745

Nieto TP, Ellis AE (1991) Heterogeneity of extracellular proteases produced by different isolates of Aeromonas hydrophila and A. sobria pathogenic for fish. J Fish Dis 14: 229-235

Norqvist A, Norrman B, Wolf-Watz H (1990) Identification and characterization of a zinc metalloprotease associated with invasion by the fish pathogen Vibrio anguillarum. Infect Immun 58:3731-3736 
Nottage AS, Birkbeck TH (1987) Production of proteinase during experimental infection of Ostrea edulis L. larvae with Vibrio alginolyticus NCMB 1339 and the antigenic relationship between proteinases produced by marine vibrios pathogenic for fish and shellfish. J Fish Dis 10: 265-273

Owens L, Austin DA, Austin B (1996) Effect of strain origin on siderophore production in Vibrio harveyi isolates. Dis Aquat Org 27:157-160

Pass DA, Dybdahl R, Mannion MM (1987) Investigations into the causes of mortality of the pearl oyster, Pinctada maxima (Jamson), in Western Australia. Aquaculture 65:149-169

Pedersen K, Gram L, Austin DA, Austin B (1997) Pathogenicity of Vibrio anguillarum serogroup O1 strains compared to plasmids, outer membrane protein profiles and siderophore production. J Appl Microbiol 82:365-371

Pena LD, Tamaki T, Momoyama K, Nakai T, Muroga K (1993) Characteristics of the causative bacterium of vibriosis in the kuruma prawn, Penaeus japonicus. Aquaculture 115: $1-12$

Pizzutto M, Hirst RG (1995) Classification of isolates of Vibrio harveyi virulent to Penaeus monodon larvae by protein profile analysis and M13 DNA fingerprinting. Dis Aquat Org 21:61-68

Prayitno SB, Latchford JW (1995) Experimental infections of crustaceans with luminous bacteria related to Photobacterium and Vibrio. Effect of salinity and $\mathrm{pH}$ on infectiosity. Aquaculture 132:105-112

Ratledge C, Dover LG (2000) Iron metabolism in pathogenic bacteria. Annu Rev Microbiol 54:881-941

Rico-Mora R, Voltolina D (1995) Effects of bacterial isolates from Skeletonema costatum cultures on the survival of Artemia franciscana nauplii. J Invertebr Pathol 66:203-204

Robertson PAW, Calderon J, Carrera L, Stark JR, Zherdmant M, Austin B (1998) Experimental Vibrio harveyi infections in Penaeus vannamei larvae. Dis Aquat Org 32:151-155

Romalde J, Lemos J, Conchas RF, Bandin S, Toranzo A (1990) Adhesive properties and other virulence factors in Yersinia ruckerii. In: Perkins OF, Chen TC (eds) Pathology in marine sciences. Academic Press, San Diego, p 123-139

Roque A, Turnbull JF, Gomez-Gil B (1998) Delivery of bioencapsulated oxytetracycline to the marine shrimp Penaeus monodon. J World Aquacult Soc 29:249-251

Roque A, Mazari A, Gomez-Gil B (2000) Oral challenge of postlarvae of Litopenaeus vannamei through bioencapsu-

Editorial responsibility: Timothy Flegel,

Bangkok, Thailand lation of Vibrio parahaemolyticus in Artemia franciscana. Cienc Mar 26:65-77

Rosenberg M, Gutnick D, Rosenberg E (1980) Adherence of bacteria to hydrocarbons: a simple method for measuring cell surface hydrophobicity. FEMS Microbiol Lett 9:29-33

Ruby EG, Nealson KH (1977) Seasonal changes in the species composition of luminous bacteria in the nearshore seawater. Limmol Oceanogr 23:530-533

Saeed MO (1995) Association of Vibrio harveyi with mortalities in cultured marine fish in Kuwait. Aquaculture 136:21-29

Santos Y, Bandin I, Bruno DW, Ellis AE, Toranzo A (1990) Comparison of the cell surface hydrophobicity of bacterial fish pathogens by different procedures. In: Perkins OF, Chen TC (eds) Pathology in marine sciences. Academic Press, San Diego, p 101-115

Schwyn B, Neilands JB (1987) Universal chemical assay for the detection and determination of siderophores. Anal Biochem 160:47-56

Song YL, Lee SP (1993) Characterization and ecological implication of luminous Vibrio harveyi isolated from tiger shrimp (Penaeus monodon). Bull Inst Zool Acad Sin 32: $217-220$

Touraki M, Rigas P, Kastritsis C (1995) Liposome mediated delivery of water soluble antibiotics to the larvae of aquatic animals. Aquaculture 136:1-10

Vazquez-Juarez R, Andlid T, Gustafsson L (1994) Cell surface hydrophobicity and its relation to adhesion of yeasts isolated from fish gut. Colloids Surf 2:199-208

Vera P, Navas JI, Quintero MC (1992) Experimental study of the virulence of three species of Vibrio bacteria in Penaeus japonicus (Bate 1881) juveniles. Aquaculture 107:119-123

Verschuere L, Heang H, Criel G, Sorgeloos P, Verstraete W (2000) Selected bacterial strains protect Artemia spp. from the pathogenic effects of Vibrio proteolyticus CW8T2. Appl Environ Microbiol 66:1139-1146

Wolf MK, Crosa JH (1986) Evidence for the role of siderophore in promoting Vibrio anguillarum infections. J Gen Microbiol 132:2949-2952

Zar JH (1999) Biostatistical analysis, 4th edn. Prentice-Hall, Upper Saddle River, NJ

Zhang XH, Austin B (2000) Pathogenicity of Vibrio harveyi to salmonids. J Fish Dis 23:93-102

Zhang XH, Meaden PG, Austin B (2001) Duplication of hemolysin genes in a virulent isolate of Vibrio harveyi. Appl Environ Microbiol 67:3161-6167

Submitted: March 27, 2001; Accepted: October 8, 2002

Proofs received from author(s): February 7, 2003 